\title{
Novel Ways of Depositing ZnTe Films by a Solution Growth Technique
}

\section{Annual Subcontract Report 1 January 1990 - 1 January 1991}

Robert W. Birkmire

Institute of Energy Conversion

University of Delaware

Newark, Delaware

SERI technical monitor: T. Basso

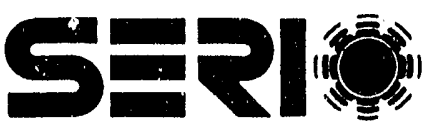

Solar Energy Research Institute 1617 Cole Boulevard Golden, Colorado 80401-3393

A Division of Midwest Research Institute Operated for the U.S. Department of Energy under Contract No. DE-AC02-83CH10093

Prepared under Subcontract No. XM-0-18110-1 
This publication was reproduced from the best a yailable camera-ready copy submitted by the subcontractor and received no editorial review at SERI.

\section{NOTICE}

This report was prepared as an account of work sponsured by an agency of the United States government. Neither the United States government nor any agency thereof, nor any of their employees. makes any warranty, express or implied, or assumes any legal liajility or responsibility for the accuracy, completeness, or usefulness of any information, apparatus, product, or process disclosed, or represents that its use would not infringe privately owned rights. Reference herein to any specific commercial product, process, or service by trade name, trademark, manufacturer, or otherwise does not necessarily constitute or imply its endorsement, recommendation, or favoring by the United States government or any agency thereof. The views and opinions of authors expressed herein do not necessarily state or reflect those of the United States government or any agency thereof.

Printed in the United States of America

Available trom:

National Technical !nformation Service

U.S. Department of Commerce

5285 Port Royal Road

Springfield, VA 22161

Price: Microfiche f.01

Printed Copy $\mathrm{AO} 3$

Codes are used for pricing all publications. The code is determined by the number of pages in the publication. Information pertaining to the pricing codes can be found in the current issue of the following publications which are generally available in most litraries: Energy Research Abstracts (ERA): Government Reports Announcements and Index (GRA and I); Scientific and Technical Abstract Reports (STA;?); and publication NTIS-PR-360 available from NTIS at the above address. 


\section{SUMLARY}

\section{A. Objectives}

The objective of this research is to develop novel processes for the deposition of thin $(<500 \AA)$ ZnTe layers suitable as transparent ohmic contacts for cds/CdTe solar cells. The processes developed for ZnTe deposition may also be applied to deposition of other II-VI semiconductor layers for polycrystalline thin film solar cells.

\section{B. Discussions}

The objectives of this research were fulfilled by the Institute of Energy Conveirsion through the performance of the following research tasks: 1) ZnTe film deposition from aqueous solutions by electrodeposition, exchange reaction with cdTe, and solution growth; 2) Doping the ZnTe films with $\mathrm{Cu}$ during deposition; 3) structural, optical and electrical characteristics of the $\mathrm{ZnTe}$ films; and 4) CdS/CdTe/ZnTe solar cells fabrication and characterization.

of the three approaches investigated for the formation of the ZnTe films, we were only successful in forming the $\mathrm{ZnTe}$ films using the electrochemical method. The films were deposited from an aqueous bath containing $0.1 \mathrm{M} \mathrm{ZnCl}_{2}$ and about $10^{-4} \mathrm{M} \mathrm{TeO}_{2}$ with the substrate externally short circuited to a $\mathrm{Zn}$ counter electrode, forming a galvanic celi. Controlling both the $\mathrm{pH}$ and $\mathrm{Te}^{+4}$ ion concentration in the solution were vital for the formation of single phase $\mathrm{znTe}$ films. Controlled p-type doping during znTe film growth was achieved by adding an aqueous solution of $\mathrm{CuCl}_{2}$ and triethanolamine (TEA) to the $\mathrm{ZnTe}$ bath. The properties of the films were characterized, and CdS/CdTe/ZnTe solar cells were fabricated.

\section{c. Conclusions}

$\mathrm{Cu}$-doped $\mathrm{ZnTe}$ films, <1000A, were reproducibly deposited for the first time by an electrochemical method. A CdTe/CdS/ITo/glass substrate is externally short circuited to a $z$ inc counter electrode in an aqueous bath consisting of $\mathrm{ZnCl}_{2}$ and $\mathrm{TeO}_{2}$ to complete an electrochemical cell. Control of both $\mathrm{pH}$ and $\mathrm{TeO}_{2}$ concentration was necessary to deposit single phase $\mathrm{ZnTe}$ films. A copper complex was added to the bath to control the $\mathrm{ZnTe}$ conductivity and dope the films p-type. CdTe/Cds solar cells using the znTe:Cu as the primary contact to the CdTe have achieved efficiencies of $\sim 9 \%$. 


\section{IIST OF CONTRIBUTORS}

Robert w. Birkmire

Brian E. McCandless

Tracey A. Yokimcus

Anup Mondal

Laurie Adkins 


\section{TABLE OF CONTENTS}

page

Summary

iii

List of Contributors

iv

List of Figures

$\mathrm{vi}$

List of Tables

vii

Section 1.0 Introduction

1.1. Background

1.2 Technical Approach 1

1.3 outline of Report 2

Section 2.0 Electrodeposition of ZnTe Films 3

Section 3.0 cdTe Devices with a znTe contact 9

Section 4.0 Other Approaches to Growing ZnTe 15

4.1 Exchange Reaction $\quad 15$

4.2 Solution Growth 15

4.3 Te and $\mathrm{ZnCl}_{2}$ Reaction 17

$\begin{array}{ll}\text { Section } 5.0 \text { Conclusions and Future Work } & 18\end{array}$

Section 6.0 References 19

$\begin{array}{ll}\text { Section } 7.0 \text { Abstract } & 20\end{array}$ 


\section{LIST OF FIGURES}

page

2-1 Schematic diagram of electrochemical cell used to deposit $\mathrm{znTe}$ films on a conductive substrate.

2-2 ZnTe film deposited as a function of deposition time.

2-3 X-ray diffraction spectrum of $\mathrm{ZnTe}$ film on 7059/ITO/ Cas/CdTe showing (a) the ZnTe (111) peak; (b) the CdTe (111) peak, and (c) the CdS (002) peak.

2-4 ZnTe:Cu film deposited as a function of deposition time.

3-1 I-V characteristics of CdS/CdTe/ZnTe:Cu cell \#4069.1.231-1 using electrodeposited ZnTe:Cu layer measured under AM 1.5.

3-2 Quantum efficiency versus wavelength of Cds/CdTe/ ZnTe: Cu cell \#40691.231-1.

3-3 Normalized transmission, $T /(1-R)$, spectrum of $7059 /$ ITO/ CdS/CdTe/ZnTe:Cu for two ZnTe:cu deposition times. 


\section{LIST OF TABLES}

page

3-1 Device parameters for CdS/CdTe/ZnTe:Cu cells using $I T O / \mathrm{Ni}, \mathrm{Cu} / \mathrm{Au}$, and $\mathrm{Ni}$ robust contacts measured under ELH simulation at $87.5 \mathrm{~mW} / \mathrm{cm}^{2}$ at $32^{\circ} \mathrm{C}$.

4-1 Reaction routes followed to deposit ZnTe by surface exchange reaction 


\section{SECTION 1.0}

\section{INTRODUCTION}

\subsection{BACKGROUND}

CaTe/Cas thin film solar cells have been shown to be a promising candidate for photovoltaic power modules $(1,2)$. Small area devices have been made by a variety of techniques with efficiencies of about $10 \%$, of which several methods are believed to be easily scaled for large area cell production. One approach uses a $n-i-p$ cell structure which takes advantage of the intrinsic nature of cdTe and solves the contact problem to the CdTe by using a p+ ZnTe:Cu layer deposited by vacuum evaporation (1). Further, cdTe based cells are candidate wide bandgap cells

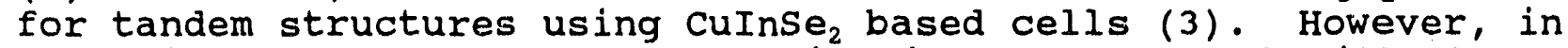
the $n-i-p$ cdTe cells, the absorption in the caTe cell with the heavily doped $\mathrm{ZnTe}$ layer is about $60 \%$ from $400 \mathrm{~nm}$ to $1300 \mathrm{~nm}$. This reduces the transmission through the device and limits the short circuit current of the narrow bandgap cell. It is thus necessary to prepare $\mathrm{ZnTe}$ having the required electronic properties but which are continuous and thin $(<500 \AA)$ to minimize the absorption. This approach has the additional advantage of permitting alternative cdTe device designs which incorporate optical enhancement. It is not possible to deposit continuous thin znTe films by vacuum evaporation. Thus, there is a need to develop an alternative deposition process to deposit thin $\mathrm{ZnTe}$ films which can improve device performance, and possibly be more cost effective for commercial applications. The objective of the research described in this report is to develop novel processes for deposition of semiconductor window/contact layers for thin film polycrystalline solar cells, specifically a method of depositing thin semitransparent ZnTe films for caTe solar cells.

\subsection{TECHNICAL APPROACH}

In order to achieve the objectives, the Institute of Energy Conversion carried out a program of investigation and analysis to deposit $\mathrm{ZnTe}$ films according to the following research tasks:

a. IEC investigated methods for depositing II-VI films using solution growth and electrochemical techniques. The processes investigated included direct $\mathrm{ZnTe}$ film formation on the cdTe surface and an exchange reaction with CdTe surface forming a $\mathrm{ZnTe}$ layer where $\mathrm{Cd}$ is replaced by $\mathrm{Zn}$. Doping of the $\mathrm{ZnTe}$ film with $\mathrm{Cu}$ to control the resistivity was an integral part of the process.

b. IEC characterized the structural, optical and electrical properties of the ZnTe films using 
established techniques of $x$-ray diffraction and total reflection and transmission measurements. Emphasis was placed on obtaining single phase films and on minimizing sub bandgap absorption.

c. IEC fabricated superstrate cds/CdTe/ZnTe solar cells to characterize the contac: properties of the $\mathrm{ZnTe}$ films on a working device. The properties of the devices using the znTe contiact were compared to devices using $\mathrm{Au}$ or $\mathrm{Cu} / \mathrm{ITO}$ as the cdTe contact. Emphasis was placed on total transmission through the device and resistivity losses due to the contact.

\subsection{CUTLINE OF REPORT}

In this report we describe an electrochemical method for depositing $\mathrm{znTe}$ films doped with $\mathrm{Cu}$ onto a ITO/CdS/CdTe cell and device result using the $\mathrm{znTe}$ contact. Also included in the report is a brief summary of other unsuccessful approaches that were investigated for depositing $\mathrm{znTe}$ films. In section 2.0 the growth and characterization of ZnTe film deposited by an electrochemical method are discussed. In section 3.0 the device performance of caTe cells using $\mathrm{ZnTe}$ as the primary contact is presented. In section 4.0 other approaches for depositing $\mathrm{ZnTe}$ films from solution are described and difficulties with growth of the films are discussed. Finally in section 4.0 , future work on transparent window/contacts is presented. 


\section{SECTION 2.0}

\section{ELECTRODEPOSITION OF ZnTE FILMS}

ZnTe films were deposited electrochemically from an unstirred aqueous bath containing $0.1 \mathrm{M} \mathrm{ZnCl}_{2}$ and about $10^{-4} \mathrm{M} \mathrm{TeO}_{2}$. The $\mathrm{TeO}_{2}$ was brought into solution by dissolving it in a solution of NaOH. The $\mathrm{pH}$ of the bath was adjusted to 3 to 4 using dilute HCl. A bath temperature of $50-60^{\circ} \mathrm{C}$ was maintained during the deposition. A conductive substrate, in most cases a 7059/ITO/CdS/CdTe sample, and a zinc electrode were externally short circuited to form an electrochemical cell as shown in Figure 2-1. A similar method has been used by Bhattacharya et al. (4) and Murali et al. (5) for depositing CdTe and case thin films respectively. The $\mathrm{zn}$ electrode acts as both a source of electrons for the cathodic reaction and as a source of $\mathrm{Zn}^{+2}$ ions via the following reaction:

$$
\mathrm{Zn} \rightarrow \mathrm{Zn}+2+2 \mathrm{e}^{-} ; \mathrm{E}_{\text {ox }}^{-}=0.76 \mathrm{~V} \text {, }
$$

where $\mathrm{E}_{\text {ox }}^{\cdot}$ is the oxidation potential with respect to the standard hydrogen electrode. The $\mathrm{TeO}_{2}$ was brought into solution by dissolving it in a solution of $\mathrm{NaOH}$, forming $\mathrm{Na}_{2} \mathrm{TeO}_{3}$. Once the bath $\mathrm{pH}$ is reduced with $\mathrm{HCl}, \mathrm{HTeO}_{2}^{+}$(tellurous asid) may form. In either form, the $\mathrm{Te}$ is in the +4 oxidation state from which it must be reduced by 4 electrons. In this report we refer to the dissolved Te forms collectively as " $\mathrm{Te}^{+4}$ ions" to simplify the discussion. Depositions were performed at $\mathrm{pH}$ from 2.0 to 5.0 of the solution and for $\mathrm{Te}^{+4}$ ion concentration from $10^{-3} \mathrm{M}$ to $10^{-5} \mathrm{M}$ to obtain the optimum conditior for growth of $\mathrm{ZnTe}$ films. The deposition rate was monitored to determine when the $\mathrm{Te}^{+4}$ ions were exhausted.

Figure 2-2 shows the time dependence of the ZnTe film deposition orito a 7059/ITO/CdS/CdTe substrate. The bath consisted $0.1 \mathrm{M}$ $\mathrm{ZnCl}_{2}$ and about $10^{-4} \mathrm{M} \mathrm{TeO}_{2}$ with a total volume of $50 \mathrm{ml}$, the bath temperature was $50-60^{\circ} \mathrm{C}$, the area of the substrate was $\sim 1.9 \mathrm{~cm}^{2}$, the bath $\mathrm{pH}$ was 3.1 to 3.3 , and the $\mathrm{zn}$ electrode area was $6 \mathrm{~cm}^{2}$. A linear growth rate was observed till about 1 hour of deposition after which it tended to saturate, suggesting exhaustion of the $\mathrm{Te}^{+4}$ ions in solution. On addition of $\mathrm{TeO}_{2}$ to the solution and adjusting the $\mathrm{pH}$, growth of $\mathrm{ZnTe}$ would proceed in a similar fashion confirming that the growth was limited by the availability of $\mathrm{Te}^{+4}$. It can be observed from Figure 2-2 that about $0.3 \mu \mathrm{m}$ ZnTe film could be grown on $\mathrm{a} \sim 1.2 \mathrm{x} \sim 1.6 \mathrm{~cm}$ substrate from a single deposition within a period of about 90 minutes using a solution volume of $50 \mathrm{ml}$. 


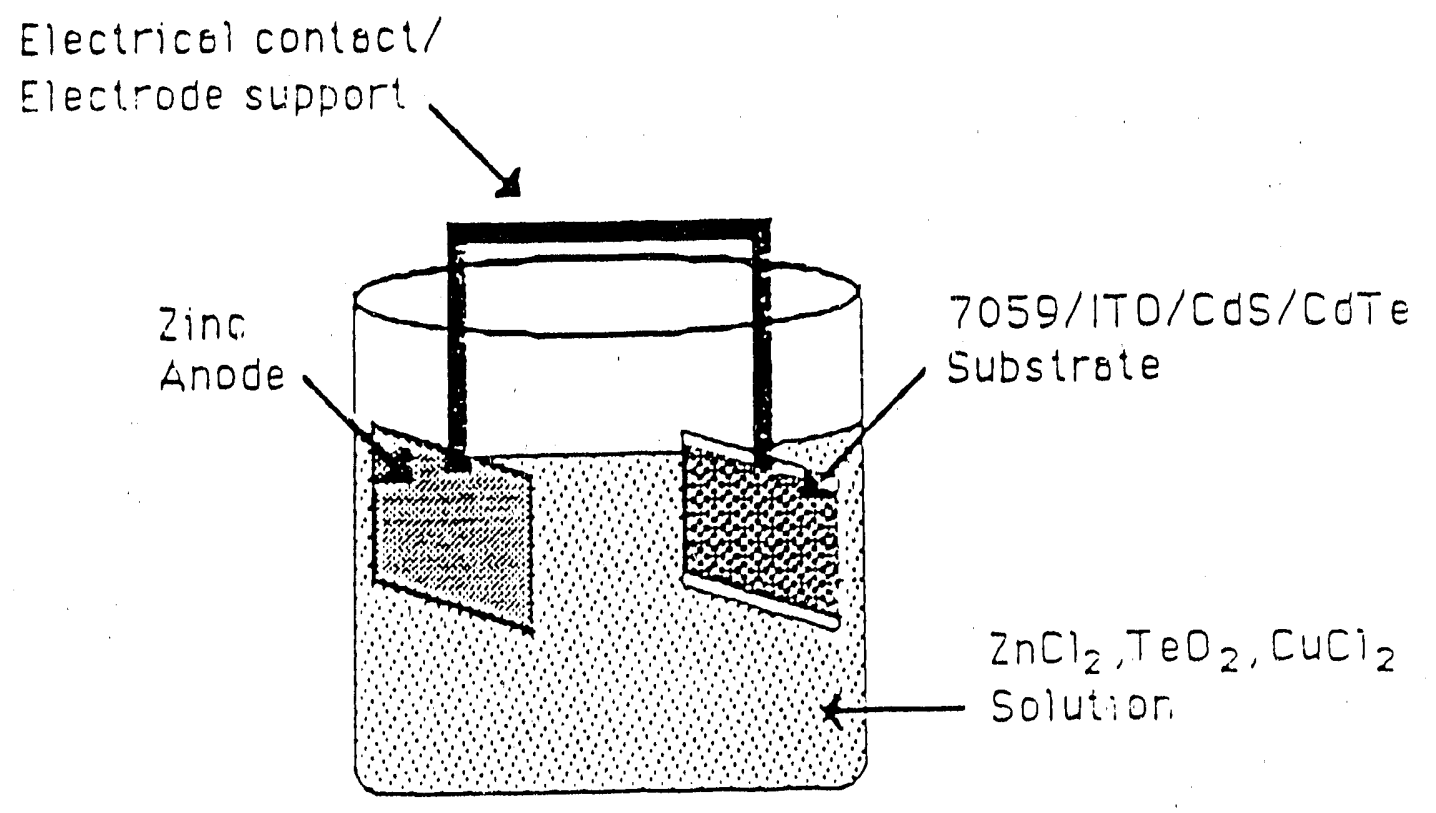

Figure 2-1. Schematic diagram of electrochemical cell used to deposit znTe films on a conductive substrate. 


\section{ZnTe Film Growth on CdTe}

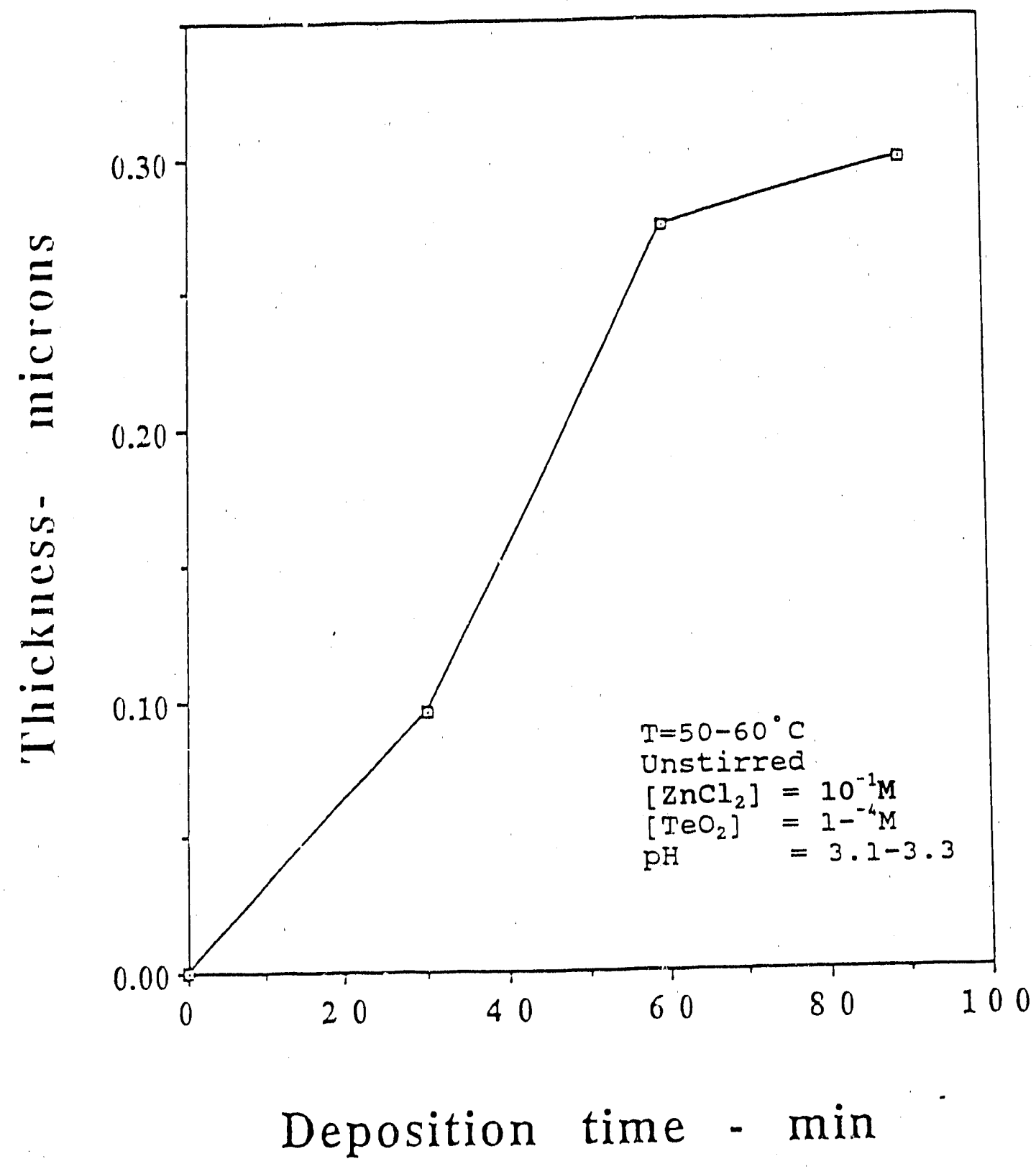

Figure 2-2. ZnTe film deposited as a function cf deposition 
controlling both the $\mathrm{pH}$ and $\mathrm{Te}^{+4}$ ion concentration in the solution were vital for the formation of the $\mathrm{znTe}$ films. A pH range of 3 to 4 and a Te concentration of $10^{-4} \mathrm{M}$ or less were found to yield single phase znTe films. At lower $\mathrm{pH}$, iree $\mathrm{Te}$ deposited and above $\mathrm{pH}=5$, the solution became cloudy, probably due to formation of $\mathrm{Zn}(\mathrm{OH})_{2}$. Increasing the $\mathrm{Te}^{+4}$ ion. concentration in solutior increased the deposition rate, however, mostly Te was found to deposit instead of $\mathrm{ZnTe}$. Since $\mathrm{Zn}$ is more electropositive than $\mathrm{Te}$, the $\mathrm{Zn}$ would be less likely to deposit as the element from its ions in an electrochemical bath than Te from its ions. Hence, low concentration of the $\mathrm{Te}^{+4}$ ions in solution must be maintained compared to the $\mathrm{zn}^{+2}$ ions, so that a diffusion-controlled process takes place for the $\mathrm{Te}^{+4}$ ins to reach the cathode.

To confirm that single phase znTe was directly formed during the growth, films 200-300 nm thick were deposited and analyzed by $x$-ray diffraction. The X-ray diffraction pattern of a typical ZnTe film deposited on 7059/ITO/CdS/Cd'l'e is shown in Figure 2-3. The sharp (111) peak at $2 \theta=25.19^{\circ}$ establishes the formation of a highly oriented cukic phase ZnTe film. The othex peaks are due to CdTe, cds, and ITO. The $x$-ray diffraction measurement, while indicating the presence of a well oriented $\mathrm{znTe}$ film, does not rule out the existence of a small quantity of excess $\mathrm{Te}$ or $\mathrm{Zn}$. The presence of excess $\mathrm{Zn}$ is unlikely in the presence of $\mathrm{Te}^{+4}$ ions since it is more electropositive and less likely to deposit. Excess $\mathrm{Te}$, on the other hand, is possible at higher $\mathrm{TeO}_{2}$ concentrations, but is detectable at low levels by reduced optical transmission in the films. Such reduction was not observed for undoped znTe films.

P-type doping of the $\mathrm{ZnTe}$ film with $\mathrm{Cu}$ was achieved by adding a copper complex to the ZnTe bath. For this, an aqueous solution of $\mathrm{CuCl}_{2}$ and triethanolamine (TEA) was added to the ZnTe bath to give $\mathrm{Cu}$ concentrations from $10^{-5}$ to $10^{-3} \mathrm{M}$. For $\mathrm{Cu}$ concentrations outside this range either no $\mathrm{Cu}$ was incorporated into the film or other compounds such as $\mathrm{Cu}_{2} \mathrm{Te}$ were formed. Figure 2-4 shows the time dependense of Cu-doped ZnTe growth on a 7059/ITO/CdS/CdTe substrate. The bath consisted $0.1 \mathrm{M} \mathrm{ZnCl}_{2}$, about $10^{-4} \mathrm{M} \mathrm{TeO}_{2}$ and $10^{-4} \mathrm{M}$ of $\mathrm{CuCl}_{2}$ in TEA with a total volume of $50 \mathrm{me}$, a pH of 3.1 to 3.3 , a substrate area of $\sim 2.5 \mathrm{~cm}^{2}$ and the same $\mathrm{zn}$ electrode described previously. The znTe:Cu films grow in a similar manner as the undoped films. The electrical properties of the $\mathrm{ZnTe:Cu}$ films were not directly measured but were inferred from cell results where fill factors were as high as $74 \%$. The Cu serves two purposes; 1 ) to dope the ZnTe and 2) to proside a source of $\mathrm{Cu}$ to dope the cdTe p-type during a subsequent $150^{\circ} \mathrm{C}$ air anneal used in the cell optimization process. 


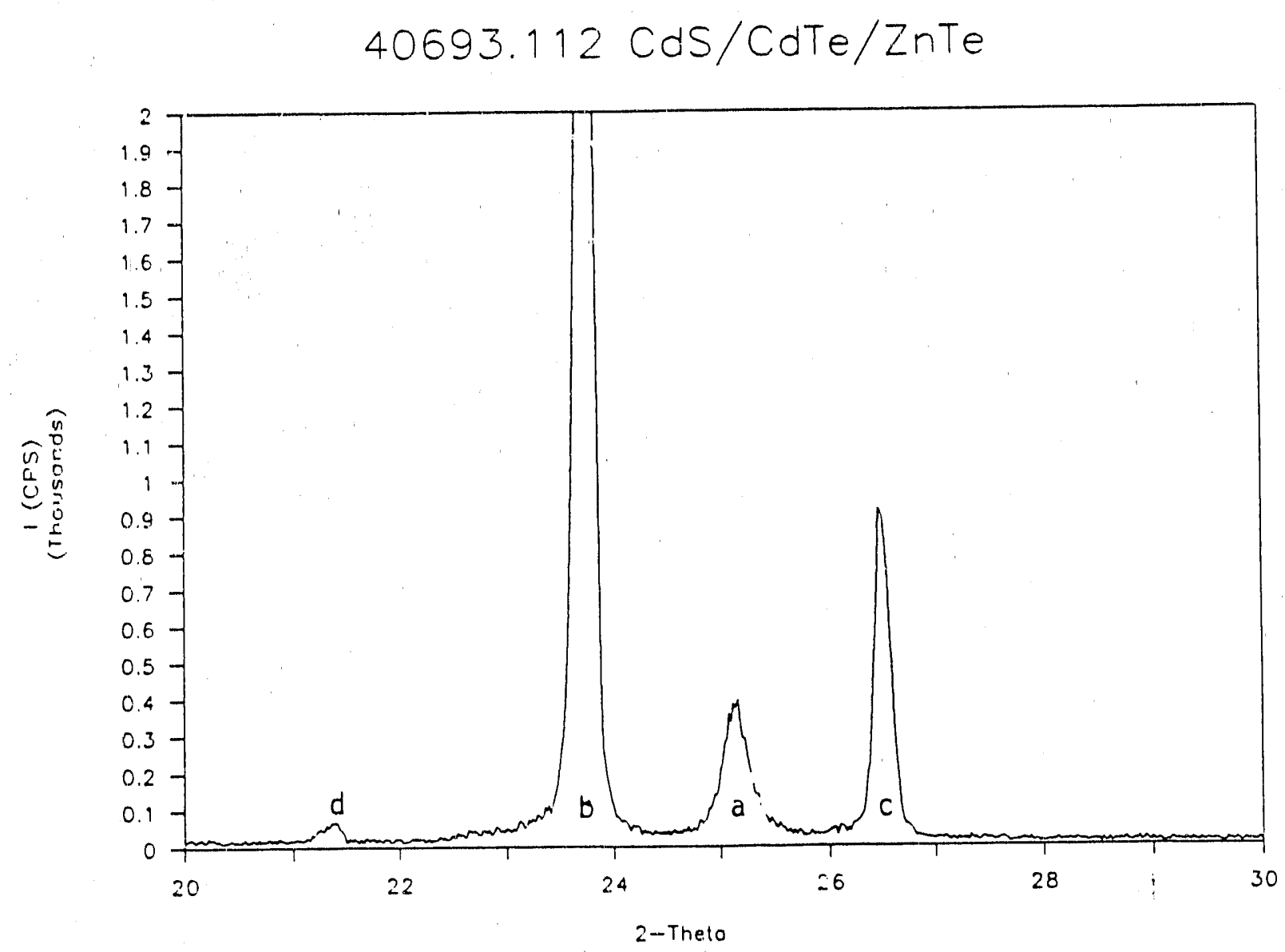

Figure 2-3. X-ray diffraction spectrum of znTe film on 7059 /ITO/Cds/CdTe showing the znTe (111) peak (a), the cate (111) peak (b), the cas (002) peak (c). and an ITO peak $\left((012) I n_{2} O_{3}\right)$ (d). 


\section{ZnTe:Cu Film Growth on CdTe}

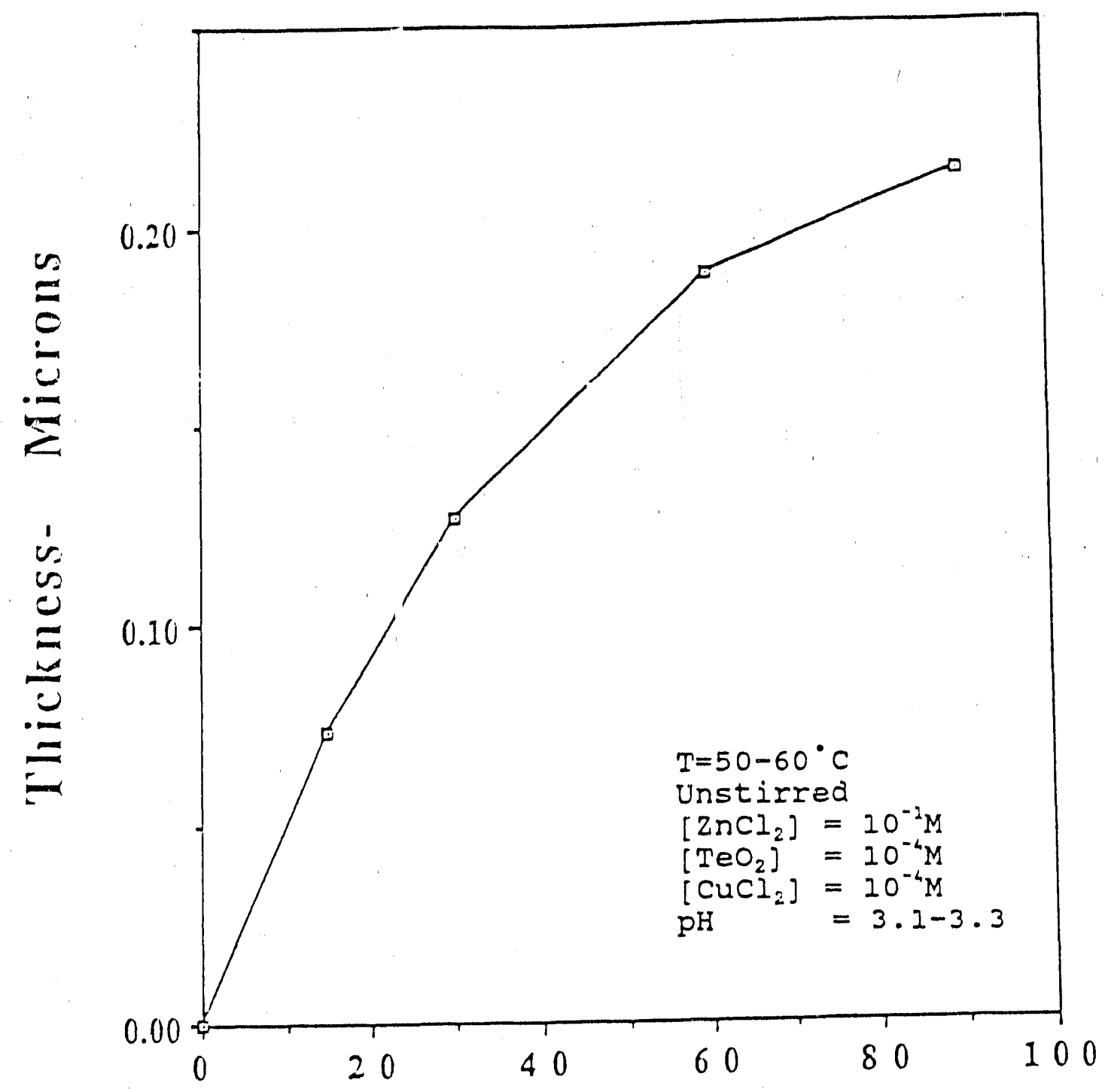

Deposition time- min

Figure 2-4. ZnTe:cu film deposited as a function of deposition time. 
For solar cell fabrication, ITO/CdS/CdTe substrates were coated with a solution of methanol containing $1 \%$ by weight of $\mathrm{CdCl}_{2}$ and then heat treated in dry air for 30 minutes at $400^{\circ} \mathrm{C}$, as described elsewhere (6). A mild, $0.01 \%, \mathrm{Br}_{2}$ methanol etch for 5 seconds was then used to remove any surface residue resulting from the heat treatment since it was found that $\mathrm{ZnTe}$ did not grow uniformiy on unetched surfaces. A $\mathrm{ZnTe}$ film, from 30 to $100 \mathrm{~nm}$ thick, doped with $\mathrm{Cu}$ was then electrochemically deposited as described above. A robust contact, either $\mathrm{Cu} / \mathrm{Au}$, $\mathrm{Ni}$ or ITO, was deposited onto the ZnTe:C.u to complete the solar cells. The area of the device was typically $0.08 \mathrm{~cm}^{2}$ and was defined by scribing. The performance of the cells was optimized in a $150^{\circ} \mathrm{C}$ air heat treatment $(6)$. I $-r$ characteristics were measured at $32^{\circ} \mathrm{C}$ under $87.5 \mathrm{~mW} / \mathrm{cm}^{2} \mathrm{ELH}$ illumination and the current was normalized to $100 \mathrm{~mW} / \mathrm{cm}^{2}$. A summary of the device cesults for cells with the best $I-V$ parameters having different contacts to the $\mathrm{ZnTe}: \mathrm{Cu}$ and three different $\mathrm{ZnTe}: \mathrm{Cu}$ thickness is presented in Table 3-1. The device results are independent of the contact metal applied to the $\mathrm{znTe}: \mathrm{Cu}$ indicating that no additional $\mathrm{Cu}$ is required.to optimize the device. It should be noted that all thin film caTe based solar cells having efficiencies greater than $9 \%$ utilize Cu, Ag, or Au in the processing, either as a p-type dopant for CdTe (7) or as a constituent of the ohmic contact to CdTe $(6,8-15)$. Several derices with $\mathrm{ZnTe}: \mathrm{Cu} / \mathrm{Cu} / \mathrm{Au}$ contacts were measured at SERI and the $I-V$ and quantum efficiency curves are shown in Figures 31 and $3-2$. 
Table 3-1

Device Parameters for CdS/CdTe/ZnTe:Cu Cells Using ITO/Ni, $\mathrm{Cu} / \mathrm{Au}$, and $\mathrm{Ni}$ robust contacts measured under EIH simulation at $32^{\circ} \mathrm{C}$ but normalized for $\mathrm{AM} 1.5$ spectrum at $100 \mathrm{~mW} / \mathrm{cm}^{2}$.

$v_{\text {oc }}$
$(V)$
0.766
0.679
0.709
0.754
0.616
0.703
0.676
0.628
0.616

ITO/Ni

$$
\begin{array}{cc}
\mathrm{J}_{\mathrm{sc}} & \mathrm{FF} \\
\left(\mathrm{mA} / \mathrm{cm}^{2}\right) & (q)
\end{array}
$$

18.4

19.4

16.6

17.8

20.5

17.2

20.6

18.6

15.6

54.6

54.2

68.3

$\mathrm{Cu} / \mathrm{Au}$

Ni

60.5

55.1

69.0

51.7

54.9

74.8
Eff

(\%)

7.7

7.1

8.0

8. 1

6.9

8.3

7.2

6.4

7.2 


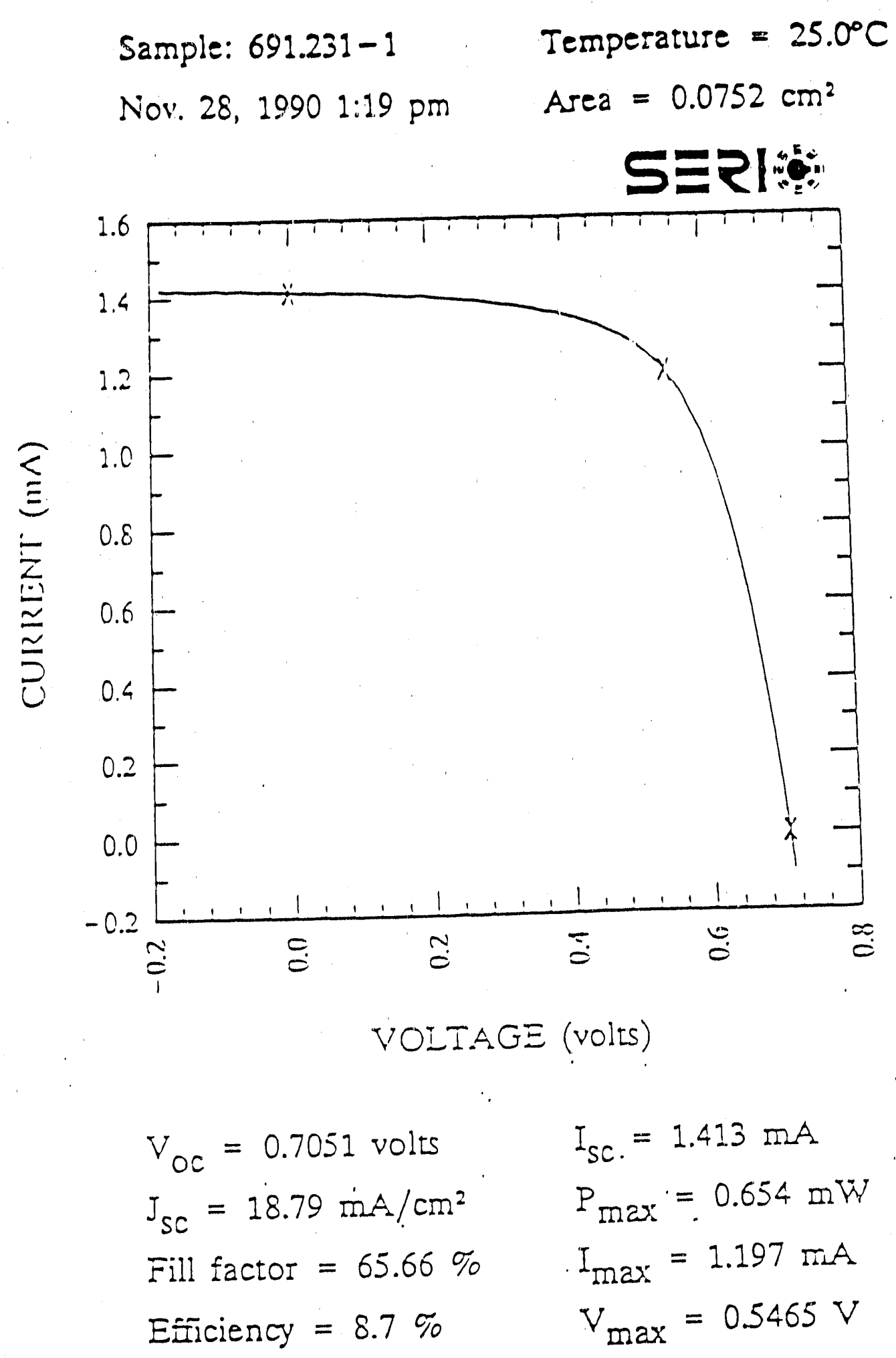

Figure 3-1. I-V characteristics of cds/CdTe/znTe:Cu cell \#40691.231-1 using electrodeposited znTe:Cu layer measured under $A M 1.5$ global solar simulation at SERI. 


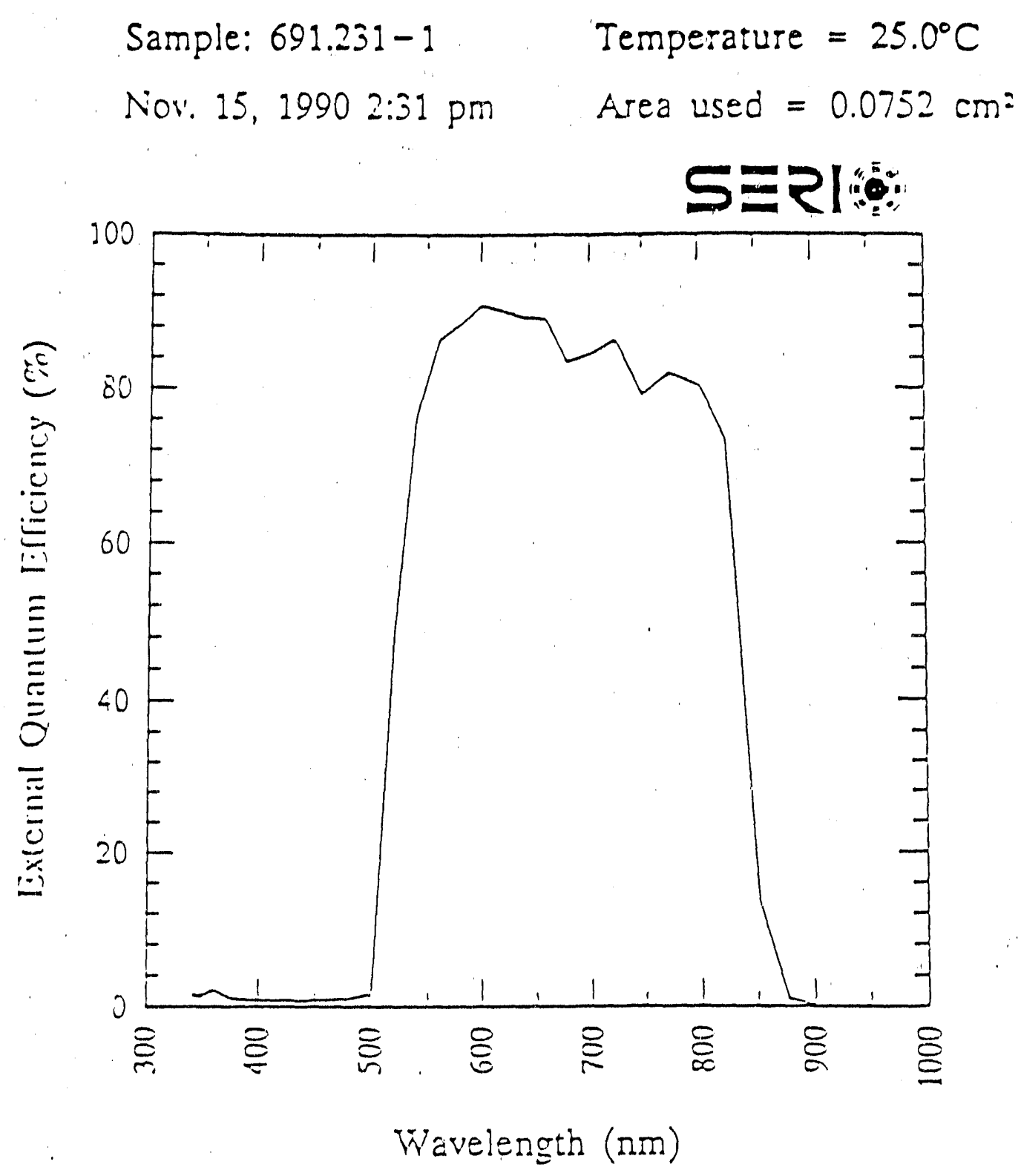

Light bias $=0.86 \mathrm{~mA}$

Zero voltage bias

Figure 3-2. Quantum efficiency versus wavelength of cds/CdTe/znTe:Cu cell \#40691.231-1. 
To evaluate the cells for tandem cell application the total transmission and reflection was measured for different deposition times, hence, thicknesses. The normalized transmission, $\mathrm{T} /(1-\mathrm{R})$, is shown in Figure 3-3 for two samples grown under similar conditions to that of Figure 2-4 but for $15 \mathrm{~min}$ and 60 minutes. The film deposited for $15 \mathrm{~min}$ was $\sim 30 \mathrm{~nm}$ thick and had $70 \%$ normalized transmission at $900 \mathrm{~nm}$. The film deposited for $60 \mathrm{~min}$ was $\sim 110 \mathrm{~nm}$ thick and had $50 \%$ normalized transmission at $900 \mathrm{~nm}$. These films bracket the deposition time/thickness used to make contacts to CdTe and the transmission results can be compared to the results reported by Meyers et al. (3) where the maximum $\mathrm{T} /(1-\mathrm{R})$ was $\sim 30 \%$ at $900 \mathrm{~nm}$. Thus, the electrodeposited $\mathrm{ZnTe}: \mathrm{Cu}$ has higher transmission than the evaporated $\mathrm{ZnTe}$ : Cu demonstrating the advantage of the very thin electrodeposited films. The ZnTe:Cu thickness and the $\mathrm{Cu}$ doping level need to be optimized further to reduce absorption. 
7059/ITO/CdS/CoTe/ZnTe:Cu Transmission

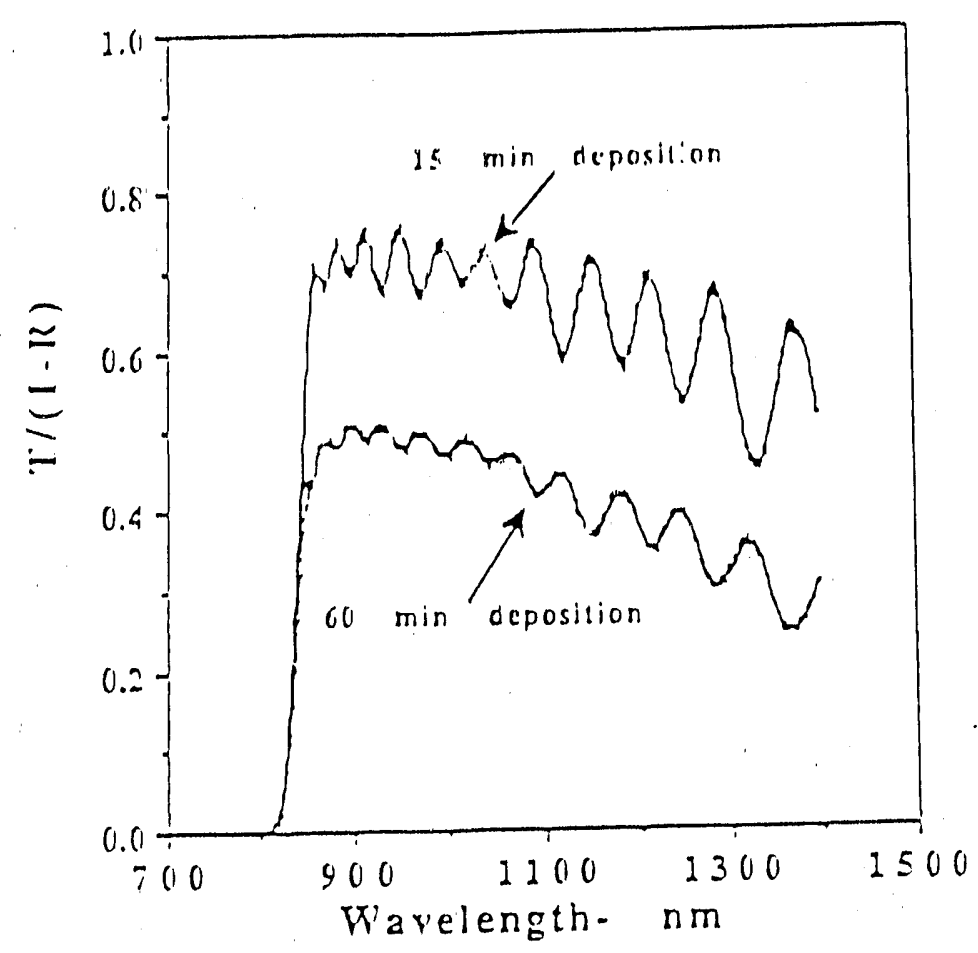

Figure 3-3. Normalized transmission, $T /(1-R)$ spectrum of $7059 /$ ITO/CdS/CdTe/ZnTe:Cu for two znTe:Cu deposition times. 


\section{SECTION 4.0}

\section{OTHER APPROACHES TO GROWING ZnTE}

Three approaches for the formation of ZnTe were investigated: 1) forming a $\mathrm{ZnTe}$ layer from the CdTe surface by an exchange reaction; 2) growing a $\mathrm{ZnTe}$ film from solution in an analogous manner to CdS; and 3) forming $\mathrm{ZnTe}$ by successive deposition of $\mathrm{zn}$ and $\mathrm{Te}$ followed by heat treatment. None of these approaches were successful; however, a brief description of each approach is presented below.

\section{1 EXCHANGE REACTION}

An exchange reaction was investigated to form the $\mathrm{ZnTe}$ film from a cdTe surface according to:

$$
(\mathrm{CdTe})_{\text {solid }}+(\mathrm{ZnLn})_{\mathrm{aq}} \rightarrow(\mathrm{ZnTe})_{\text {solid }}+(\mathrm{CdLn})_{\mathrm{aq}}
$$

where $\mathrm{In}$ is an appropriate ligand. Table 4-1 lists the reaction routes pursued along with the corresponding standard free energies of reaction. The following growth conditions were varied: solution temperature- 25 to $80^{\circ} \mathrm{C}$, concentration- 0.03 to 3 molar, $\mathrm{pH}-2.3$ to 8.5 (basic solution only for $\mathrm{ZnCl}_{2}$ reaction) and reaction time- 5 to $10 \mathrm{~min}$. For these three reaction paths no $\mathrm{ZnTe}$ films were formed.

\subsection{SOLUTION GROWTH}

Two different chemistries were explored to form $\mathrm{ZnTe}$ by solution growth:

1. A solution of $\mathrm{Na}_{2} \mathrm{Te}$ was prepared from $\mathrm{Te}$ powder, $\mathrm{NaOH}$ and $\mathrm{Na}_{2} \mathrm{~S}_{2} \mathrm{O}_{4}$ as a source of $\mathrm{Te}^{-2}$ ions. $\mathrm{Zn}\left(\mathrm{C}_{2} \mathrm{H}_{3} \mathrm{O}_{2}\right)_{2}$ was added as the source of $\mathrm{Zn}$ with $\mathrm{NH}_{3}$ as a complexing agent. A small amount of Te precipitate was formed in the solution but no ZnTe was formed.

2. $\mathrm{Zn}$ metal was used as a reducing agent and a source of $\mathrm{Zn}$ using the following:

$\mathrm{Zn}(\mathrm{solid}) \rightarrow \mathrm{Zn}^{+2}+2 \mathrm{e}^{-}$

$\mathrm{TeO}_{2}+6 \mathrm{e}^{-} \rightarrow \mathrm{Te}^{-2}$

$\mathrm{Zn}^{+2}+\mathrm{Te}^{-2} \rightarrow \mathrm{ZnTe}(\mathrm{solid})$

$\mathrm{Zinc}$ dust was gradually added to a solution of $\mathrm{TeO}_{2}$ and $\mathrm{NaOH}$. This resulted in the formation of $\mathrm{Zno}$ and crystalline $\mathrm{Te}$. The solution had a reddish color suggesting the presence of elemental tellurium rather than the $\mathrm{Te}^{-2}$ ions needed for the reaction. 
Table 4-1

Reaction Routes Followed to Deposit znTe by

Surface Exchange Reaction

Standard Free Energy

of Reaction (Kcal/mole)

Cyanide Route

$\mathrm{CdTe}_{(s)}+\mathrm{Zn}(\mathrm{CN})_{4} \rightarrow \mathrm{ZnTe}_{(s)}+\mathrm{Cd}(\mathrm{CN})_{4}$

$\begin{array}{llll}-25.6 & -22.92 & -28.05 & -25.78\end{array}$

$-5.31$

Chloride Route

$\mathrm{CdTe}_{(\mathrm{s})}+\mathrm{ZnCl}_{2} \rightarrow \mathrm{ZnTe}_{(\mathrm{s})}+\mathrm{CdCl}_{2}$

$\begin{array}{llll}-25.6 & -0.84 & -28.05 & -3.43\end{array}$

$-5.04$

Acetate Route

$\mathrm{CdTe}_{(\mathrm{s})}+\mathrm{Zn}\left(\mathrm{C}_{2} \mathrm{H}_{3} \mathrm{O}_{2}\right)_{2} \rightarrow \mathrm{ZnTe}_{(\mathrm{s})}+\mathrm{Cd}\left(\mathrm{C}_{2} \mathrm{H}_{3} \mathrm{O}_{2}\right)_{2}$

$-25.6+-2.06 \quad-28.05 \quad-2.06$

$-2.45$ 


\subsection{Te AND $\mathrm{ZnCl}_{2}$ REACTION}

Experiments to form $\mathrm{ZnTe}$ by successive formation of $\mathrm{Te}$ and $\mathrm{Zn}$ followed by annealing were performed. Conductive substrates of $7059 / \mathrm{Pt}$ were used on which $\mathrm{T} \epsilon$ was electrochemically deposited from dilute solutions of $\mathrm{TeO}_{2}, 10^{-4}$ to $10^{-5} \mathrm{M}$, at a $\mathrm{pH}$ of 2 to 3 with an $\mathrm{Al}$ or $\mathrm{Zn}$ electrode externally connected to the substrate. The samples were then coated with $\mathrm{ZnCl}_{2}$ in $\mathrm{MeOH}$ and heat treated in $\mathrm{H}_{2} / \mathrm{Ar}$ at $400^{\circ} \mathrm{C}$ for 30 minutes. No $\mathrm{ZnTe}$ films were formed but PtTe was formed as determined from XRD. Further experiments using this approach with CdTe substrates did not yield $\mathrm{ZnTe}$. 


\section{CONCLUSIONS AND FUTURE WORK}

Cu-doped ZnTe films, $<100 \mathrm{~nm}$, were deposited for the first time by an electrochemical method in which a CdTe/CdS/ITO/glass substrate is externally short circuited to a zinc counter electrode in an aqueous bath consisting of $\mathrm{ZnCl}_{2}$ and $\mathrm{TeO}_{2}$ to complete an electrochemical cell. Control of both $\mathrm{pH}$ and $\mathrm{TeO}_{2}$ concentration was necessary to deposit single phase ZnTe films. A copper complex added to the bath allowed controllable p-type doping of the $\mathrm{ZnTe}$ films. CaTe/Cas solar cells using the $\mathrm{ZnTe}: \mathrm{Cu}$ as the primary contact to the cdTe achieved efficiencies of $8.7 \%$ verified by SERI. The optical transmission of cells using ZnTe:Cu made in this manner is higher than on cells using evaporated $\mathrm{ZnTe}: \mathrm{Cu}$, making this an attractive contacting methoa f or tandem cells and for use of optical back surface reflection enhancement techniques in conjunction with thin cdTe.

We have also obtained promising results using this method to deposic $\mathrm{ZnSe}$ from an aqueous bath containing $\mathrm{ZnCl}_{2}$ and $\mathrm{SeO}_{2}$ directly onto Mo/7059 and CuInSe $/$ Mo/7059 substrates. We have also deposited CdS films onto ITO/7059 superstrates for CdTe/CdS cells. These applications of the method demonstrate its utility for depositing II-VI compound semiconductor window layers. Future work will include fabrication and characterization of $\mathrm{znse}$ and cas layers and evaluation of devices using them. 


\section{SECTION 6.0}

\section{REFERENCES}

1. P.V. Meyers, Solar Cells 23, 59 (1988).

2. J.F. Jordan and S.P. Albright, Solar Cells 23, 107 (1988).

3. P.V. Meyers, C.H. Liu, L. Russell, V. Ramanathan, R.W.

Birkmire, B.E. McCandless and J.E. Phillips, Proc. 20 th IEEE PVSC, 1448 (1988).

4. R.N. Bhattacharya, K. Rajeshwar, and R.N. Noufi, J. Elec. Chem. Soc., 939 (April 1984).

5. K.R. Murali, I. Radhakrishna, R.N. Rao, V.K. Venkatesan, Jour. Mat. Sci., 25, 3521 (1980).

6. Final report to SERI, Contract XI-9-19032-1, (1990).

7. M. Ondris, M. Pichler, and R. Brownfield, US Patent $\# 4,909,857$, (1990).

8. C.G. Morris, P.G. Tanner and A. Tottszer, Proc. 21st IEEE, 575 (1990).

9. N. Suyama, T. Arita, Y. Nishiyama, N. Veno, S. Kitamura, and M. Murozono, Proc. 21st IEEE PVSC, 498, (1990).

10. A. Rohatgi, S.A. Ringel, R. Sudharsanan, P.V. Meyers, C.H. Liu, and V. Ramanathan, Solar Cells 27,219 (1989).

11. J.F. Jordan and S.P. Albright, Solar Cells 23, 107 (1988).

12. P.V. Meyers, Solar Cells 23, 59 (1988).

13.? K.W. Mitchel1, C. Eberspacher, F. Cohen, J. Avery, G. Duran, and W.R. Bottenberg, Proc. 18th IEEE PVSC, P. ?, (1985).

14. H. Matsumoto, K. Kuribayashi, H. Uda, Y. Kamatsu, A. Nakano, and S. Ikegami, Solar Cells 11, 367 (1984).

15. B.M. Basol, Jour. Appl. Phys. 55(1), 601 (1984). 


\section{ABSTRACT}

Results of a research program to develop a method to deposit thin, <50 nm, znTe films as a transparent back contact to caTe solar cells are presented. Several approaches to grow $\mathrm{ZnTe}$ film from aqueous solutions were investigated including

electrodeposition, formation of ZnTe from the CdTe surface by an exchange reaction and direct formation of $\mathrm{ZnTe}$ from a chemical solution. Methods to dope the $\mathrm{ZnTe}$ films with $\mathrm{Cu}$ were an integral part of the program. of the three approaches, only the electrochemical method was successful. The films were deposited from an aqueous bath containing $\mathrm{ZnCl}_{2}$ and $\mathrm{TeO}_{2}$ with the substrate externally short circuited to a $\mathrm{zn}$ counter electrode to form $a$ galvanic cell. Controluing both the $\mathrm{pH}$ and $\mathrm{Te}^{+4}$ ion

concentration in the solution were critical for the formation of single phase znTe films. A copper complex was added to the bath to control the ZnTe conductivity and dope the films p-type.

cdTe/CdS solar cells using the $\mathrm{ZnTe}$ : $\mathrm{Cu}$ as the primary contact to the cdTe have achieved efficiencies of $\sim 9 \%$. 


\begin{tabular}{|c|c|c|c|}
\hline $\begin{array}{c}\text { Document Control } \\
\text { Page }\end{array}$ & $\begin{array}{l}\text { 1. SERI Report No. } \\
\text { SERI/TP-210-4319 }\end{array}$ & $\begin{array}{l}\text { 2. NTIS Accession No. } \\
\text { DE91002190 }\end{array}$ & 3. Recipient's Accession No. \\
\hline \multirow{2}{*}{\multicolumn{3}{|c|}{$\begin{array}{l}\text { 4. Title and Subtitle } \\
\text { Novel Ways of Depositing ZnTe Films by a Solution Growth Technique }\end{array}$}} & $\begin{array}{l}\text { 5. Publication Date } \\
\text { June } 1991\end{array}$ \\
\hline & & & 6. \\
\hline \multicolumn{3}{|l|}{$\begin{array}{l}\text { 7. Author(s) } \\
\text { Robert W. Birkmire }\end{array}$} & 8. Performing Organization Rept. No. \\
\hline \multirow{2}{*}{\multicolumn{3}{|c|}{$\begin{array}{l}\text { 9. Pertorming Organization Name and Address } \\
\text { Institute of Energy Conversion } \\
\text { University of Delaware } \\
\text { Newark, Delaware }\end{array}$}} & $\begin{array}{l}\text { 10. Project/TaskWork Unit No. } \\
\text { PV121104 }\end{array}$ \\
\hline & & & $\begin{array}{l}\text { 11. Contract (C) or Grant }(G) \text { No. } \\
\text { (C) XM-0-18110-1 } \\
\text { (G) }\end{array}$ \\
\hline \multirow{2}{*}{\multicolumn{3}{|c|}{$\begin{array}{l}\text { 12. Sponsoring Organization Name and Address } \\
\text { Solar Energy Research Institute } \\
1617 \text { Cole Blvd. } \\
\text { Golden, CO } 80401-33 \$ 3\end{array}$}} & $\begin{array}{l}\text { 13. Type of Repont \& Period Covered } \\
\text { Technical report, } \\
1 \text { January } 1990-1 \text { January } 1991 \\
\end{array}$ \\
\hline & & & 14. \\
\hline \multicolumn{4}{|c|}{$\begin{array}{l}\text { 15. Supplementary Notes } \\
\text { SERI technical monitor: T. Basso, (303) 231-7035 }\end{array}$} \\
\hline \multicolumn{4}{|c|}{$\begin{array}{l}\text { 16. Abstract (Limit: } 200 \text { words) } \\
\text { This report describes a research program to develop a method for depositing thin (<50 nm) } \mathrm{ZnTe} \text { films to form a transparent } \\
\text { back contact to CdTe solar cells. We investigated several approaches to growing } \mathrm{ZnTe} \text { films from aqueous solution, including } \\
\text { electrodepositing the films, forming the films from the CdTe surface by an exchange reaction, and forming the films from a } \\
\text { chemical solution. Methods to dope the } \mathrm{ZnTe} \text { films with } \mathrm{Cu} \text { were another integral part of the program. Of the three approaches, } \\
\text { only the electrochemical method was successful. In this approach, the films were deposited from an aqueous bath containing } \\
\mathrm{ZnCl} \mathrm{I}_{2} \text { and } \mathrm{TeO}_{2} \text { with the substrate externally short-circuited to a } \mathrm{Zn} \text { counter electrode to form a galvanic cell. Controlling both } \\
\text { the } \mathrm{pH} \text { and } \mathrm{Te}^{+4} \text { ion concentration in the solution were critical for forming the single-phase } \mathrm{ZnTe} \text { films. A copper complex was } \\
\text { added to the bath to control the } \mathrm{ZnTe} \text { conductivity and dope the films p-type. CdTe/CdS solar cells were developed incorporating } \\
\text { the } \mathrm{ZnTe}: \mathrm{Cu} \text { as the primary contact to the CdTe. These cells have exhibited efficiencies of } \sim 9 \% \text {. }\end{array}$} \\
\hline \multicolumn{4}{|c|}{$\begin{array}{l}\text { 17. Document Analysis } \\
\text { a. Descriptors } \\
\text { photovoltaics ; solar cells ; polycrystalline thin films ; film growth ; deposition } \\
\text { b. Identifiers/Open-Ended Terms }\end{array}$} \\
\hline \multicolumn{4}{|l|}{$\begin{array}{l}\text { c. UC Categuries } \\
273\end{array}$} \\
\hline \multirow{2}{*}{\multicolumn{3}{|c|}{$\begin{array}{l}\text { 18. Availability Statement } \\
\text { National Technical Information Service } \\
\text { U.S. Department of Commerce } \\
5285 \text { Port Royal Road } \\
\text { Springfield, VA } 22161\end{array}$}} & $\begin{array}{l}\text { 19. No. of Pages } \\
29 \\
\end{array}$ \\
\hline & & & $\begin{array}{l}\text { 20. Price } \\
\text { Aิษ3 }\end{array}$ \\
\hline
\end{tabular}

Form No. 0069E (6-30-87) 

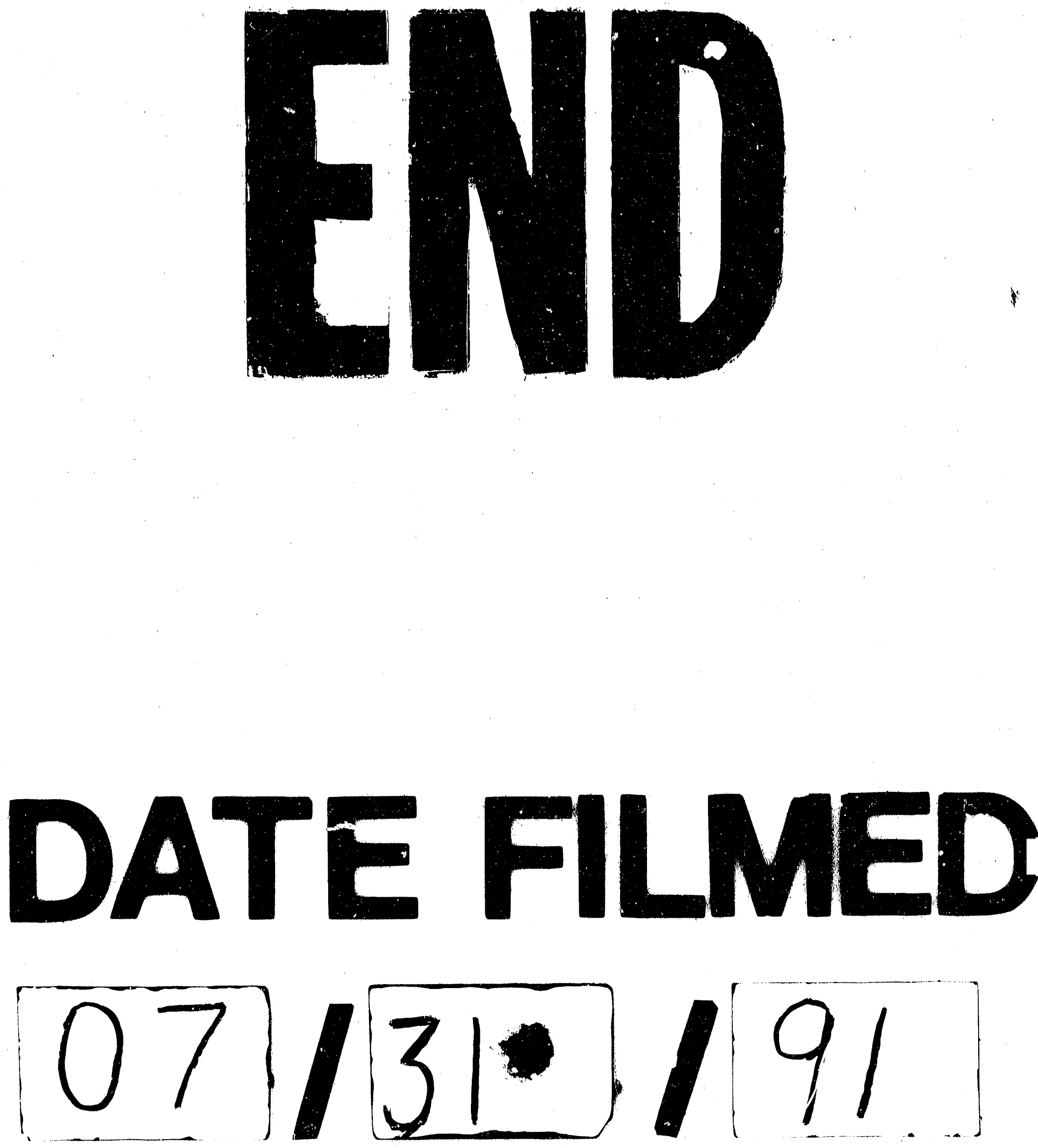
$=$

$=$ 